ligands reduced the ability of PSD95 to potentiate synaptic transmission in hippocampal slice cultures, and proteins containing both mutations had no potentiating effect. Pharmacological experiments also showed that neither the calcium/calmodulindependent protein kinase II (CaMKII) cascade, which is involved in LTP, nor the mitogen-activated protein kinase (MAPK) signalling pathway, elements of which interact with PSD95, was needed for the effects of PSD95. It seems likely that PSD95 acts downstream of these signalling pathways, through a mechanism that requires it to associate with the membrane and to bind to other proteins through its PDZ domains.

Rachel Jones

\section{(i) References and links} ORIGINAL RESEARCH PAPER Ehrlich, I. \& Malinow, R. Postsynaptic density 95 controls AMPA receptor incorporation during long-term potentiation and experience-driven synaptic plasticity. J. Neurosci. 24, 916-927 (2004) FURTHER READING Stein, V. et al. Postsynaptic density-95 mimics and occludes hippocampal long-term potentiation and enhances long-term depression. J. Neurosci. 23, 5503-5506 (2003)

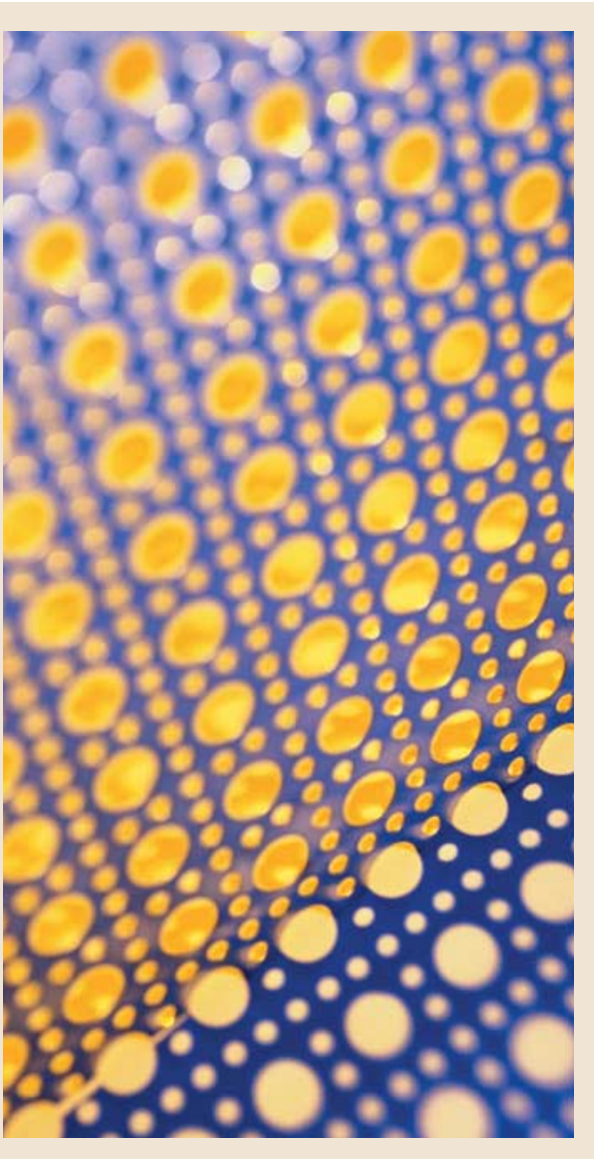

IN THE NEWS

\section{Where now for primate research?}

The decision to scrap plans to build a primate research centre in Cambridge, $\mathrm{UK}$, is a severe blow for research into brain disease, according to leading scientists. Colin Blakemore, the chief executive of the Medical Research Council, said "current research in primates is offering hope of treatments for Alzheimer's, Parkinson's, Huntington's disease and strokes" (Daily Telegraph, UK, 28 January 2004). Mark Walport, the director of the Wellcome Trust, agreed "research using primates will continue to be essential if we are to conquer many diseases. Without facilities such as those planned for the Cambridge University site this kind of medical pioneering work will be severely hampered" (Daily Telegraph).

Although rising costs were cited as the main reason for abandoning the project, the move was widely perceived as a victory for the animal rights movement. Cambridge is certainly no stranger to animal rights protestors - Huntingdon Life Sciences, a contract research facility that is based just outside the city, has been the target of a sustained campaign by such groups, including a physical attack on its managing director, Brian Cass. Cass was quoted as saying "we in the research community have been assured of the support of the Government ... but this decision is saying that violence and illegal protest works" (Daily Telegraph).

Not surprisingly, animal rights groups welcomed the decision. Andrew Tyler of Animal Aid said, "it would have been a factory to mutilate the brains of monkeys and then dispose of them. It would have made Cambridge University the monkey torture capital of Europe" (Daily Telegraph). In the Guardian (UK, 28 January), Wendy Higgins, the campaigns director at the British Union for the Abolition of Vivisection, wrote "despite attempts to convince us most animals suffer nothing more than a pin prick, there is growing public disquiet about vivisection. We too want to see cures for human diseases but making animals suffer is not the most credible way of reaching that goal."

Nevertheless, the national press in the UK largely supported the view that primate research should continue. A Guardian leader article argued "what would have made the public more uncomfortable was the use of monkeys. But this places emotion before reason. Colin Blakemore ... is right to point to the many medical breakthroughs which would not have been achieved without them."

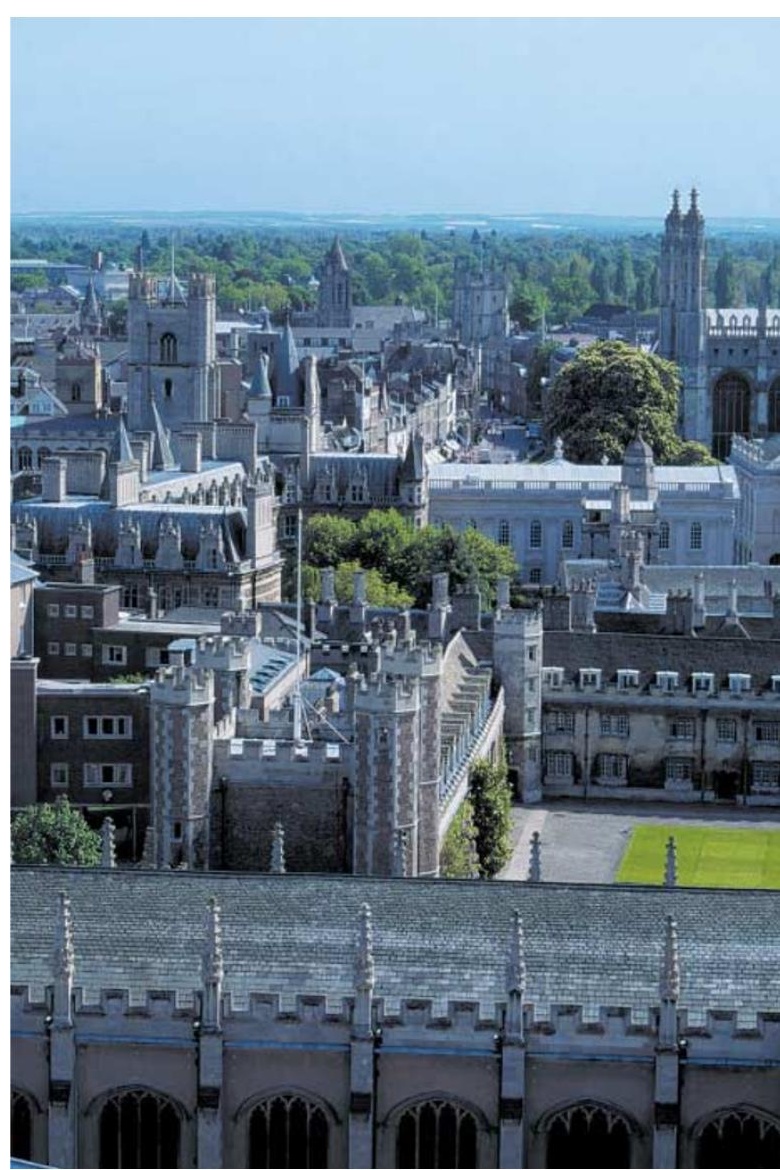

The Independent (UK, 28 January), however, took a different line: "the right decision has been taken ... but for the wrong reasons. To keep animals so similar to ourselves in laboratory conditions is an unacceptable cruelty, and to experiment on them is a violation of rights that should be extended to these, our near relatives." However, the article went on to say that the University's decision to abandon the project was "born out of fear: of the unreasonable violence of animal rights campaigners," and that scientists "should stop violating the rights of the higher primates because they are persuaded it is wrong, not because they are intimidated by baseball bats and bricks."

Blakemore, who has frequently been targeted by anti-vivisection groups himself, refuses to be deterred: "They will not win. We will try to make sure [the research] goes on in Cambridge but, if not, it will go on elsewhere in the world eventually and it will be patients who benefit" (Times, UK, 28 January).

Heather Wood 